\title{
PEMILIHAN SUPPLIER PADA APOTEK PUSAKA ARTA DENGAN METODE ANALYTICAL HIERARCHY PROCESS (AHP) DAN SIMPLE ADDITIVE WEIGHTING (SAW)
}

\author{
Elfy Susanti ${ }^{1)}$, Rusdah ${ }^{2)}$ \\ ${ }^{1}$ Sistem Informasi, Fakultas Teknologi Informasi, Universitas Budi Luhur \\ ${ }^{1,2} \mathrm{Jl}$. Raya Ciledug, Petukangan Utara, Kebayoran Lama, Jakarta Selatan 12260 \\ E-mail : elvy743@gmail.com ${ }^{1)}$, rusdah@budiluhur.ac.id ${ }^{2)}$
}

\begin{abstract}
Abstrak
Supplier merupakan peran penting dalam bisnis yang bekerjasama dalam proses ketersediaan obat. Apotek Pusaka Arta merupakan salah satu apotek swasta dibawah naungan Koperasi Pegawai Perum Peruri, yang bergerak di bidang farmasi, dalam proses pengadaan obat-obatan pihak Apotek Pusaka Arta memiliki banyak supplier. Proses pemilihan supplier yang tidak mudah dan kurang tepat akan berdampak pada ketersediaan obat. Dalam menentukan supplier, Apotek Pusaka Arta hanya berdasarkan pada diskon yang ditawarkan dan pengiriman yang cepat sehingga proses pemilihan supplier tidak mudah dan juga penyimpanan yang dilakukan untuk menyimpan data supplier kurang memadai. Masalah dalam memenuhi pesanan obat (order) yang dapat merugikan apotek, seperti jumlah obat yang dikirim tidak sesuai dengan pesanan, adanya kemasan yang rusak, dan tanggal kadaluarsa yang dekat. Penelitian ini bertujuan untuk mengembangkan sebuah sistem penunjang keputusan supplier terbaik menggunakan metode Analytical Hierachy Process (AHP) dan Simple Additive Weighting (SAW). Hasil dari penelitian ini nilai bobot pada kriteria kemasan (0,1051), tanggal kadaluarsa $(0,1619)$, waktu pengiriman $(0,1127)$, jumlah kirim $(0,2254)$, diskon $(0,1932)$, tempo pembayaran $(0,2017)$, dengan hasil uji consistensi ratio sebesar 0,0536. Sistem penunjang keputusan penentuan supplier terbaik yang dirancang dapat membantu dalam melakukan penilaian supplier terbaik yang lebih mudah, dan cepat.
\end{abstract}

Kata kunci: Sistem Penunjang Keputusan, AHP, SAW, Supplier

\section{PENDAHULUAN}

Apotek Pusaka Arta merupakan salah satu apotek swasta dibawah naungan Koperasi Pegawai Perum Peruri, yang bergerak di bidang farmasi, dalam proses pengadaan obat-obatan pihak Apotek Pusaka Arta memiliki banyak supplier. Supplier merupakan bagian terpenting di dalam apotek, sehingga pemilihan supplier yang tepat akan berpengaruh pada tersedianya obat dan kegiatan di apotek bisa berjalan dengan lancar tanpa terhambat. Proses pemilihan supplier tidak mudah, karena saat apotek sudah bekerja sama dengan supplier maka akan berpengaruh pada kegiatan apotek. Oleh karena itu perlu dibuat sebuah sistem yang dapat mempermudah proses pemilihan supplier.

Proses pemilihan supplier yang kurang tepat akan berdampak pada ketersediaan obat. Dalam menentukan supplier, Apotek Pusaka Arta hanya berdasarkan pada diskon yang ditawarkan dan pengiriman yang cepat sehingga proses pemilihan supplier tidak mudah dan juga penyimpanan yang dilakukan untuk menyimpan data supplier kurang memadai. Masalah dalam memenuhi pesanan obat (order) yang dapat merugikan apotek, seperti jumlah obat yang dikirim tidak sesuai dengan pesanan, adanya kemasan yang rusak ,dan tanggal kadaluarsa yang dekat. Hal-hal tersebutlah yang membuat proses pengambilan keputusan ini perlu . Dengan adanya sistem penunjang keputusan dalam memilih supplier maka diharapkan dapat membantu dalam pengambilan keputusan yang dilihat dari hasil nilai serta memberikan pertimbangan untuk memilih supplier.

Dari beberapa penelitian terdahulu dapat diterapkan pada berbagai bidang permasalahan, diantaranya: mengenai Pemilihan Supplier Pada Apotek Dengan Metode AHP dan SAW (Studi Kasus Apotek XYZ), dalam penelitian ini menggunakan Analytical Hierarchy Process (AHP) dari kelima kriteria yang sudah ditentukan oleh apotek yaitu diskon, tempo pembayaran, waktu pengiriman, Kemasan, dan Expired Date [1]. Kemudian pemilihan Supplier Obat Yang Tepat Dengan Metode Simple Additive Weighting, dalam penelitian ini menggunakan Simple Additive Weighting penilaian supplier yang terdiri dari kriteria Kualitas 25\%, Harga 10\%, Petunjuk Kegunaan 10\%, Garansi 15\%, Pengemasan 10\%, Pemenuhan Pesanan 15\%, Pelayanan $15 \%$ [2].

Dalam penelitian ini pemilihan supplier di Apotek Pusaka Arta ada 6 kriteria yaitu: diskon, tempo pembayaran, waktu pengiriman, jumlah kirim, kemasan, dan tanggal kadaluarsa. Karna belum adanya bobot maka menggunakan metode Analitycal Hierarchy Process (AHP). Dan penilaian kriteriakriteria beragam maka menggunakan Metode Simple Additive Weighting (SAW). 


\section{METODE PENELITIAN}

2.1. Metode Analitycal Hierarchy Process (AHP) dan Simple Addtive Weighting (SAW)

Metode Analitycal Hierarchy Process AHP dikembangkan oleh Saaty pada tahun 1976 . AHP merupakan salah satu alat yang paling banyak digunakan dalam pengambilan keputusan multikriteria untuk pemecahan masalah dalam dunia nyata. Keuntungan lain dari metode ini adalah penggunaan hierarki struktur multi-periode, multiorang dan multi-kriteria untuk masalah yang kompleks, karena langkah-langkah dari solusi termasuk mengkonfigurasi hierarki ini dan sintesis hasil penilaian [3]. Menyusun hierarki tujuan utama sebagai level teratas, kemudian level hierarki dibawahnya yang disusun yaitu kriteria-kriteria yang mempertimbangkan dan menentukan alternatif tersebut, dilanjutkan dengan menyusun sub kriteria. Gambar 2.1 merupakan gambar struktur hierarki. Dan perhitungan consistency ratio (CR) yang dianggap baik apabila $\mathrm{CR} \approx 0,1$.

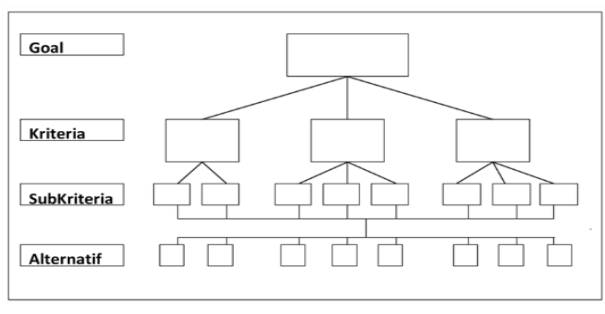

Gambar 1. Struktur Hierarki

Metode SAW dikenal dengan istilah metode penjumlahan terbobot. Konsep dasar metode SAW yaitu mencari perhitungan bobot dari setiap alternatif dan atribut keuntungan atau biaya [4] Dan proses normalisasi matriks keputusan memiliki formula yaitu:

$$
r_{\mathrm{ij}}=\left\{\begin{array}{ll}
\frac{x_{\mathrm{ij}}}{\operatorname{Max} x_{\mathrm{ij}}} & \operatorname{Min}_{\mathrm{ij}} \\
\dot{i} & \frac{i}{X_{\mathrm{ij}}}
\end{array} \text { jika j adalah attribut } \mathrm{k}\right.
$$

\subsection{Metode Pengumpulan Data}

Dalam mengumpulkan data penulis melakukan dengan cara wawancara, observasi, studi pustaka, dan analisa dokumen.

a. Wawancara

Wawancara merupakan kegiatan tanya jawab yang dilakukan dengan pegawai bagian pembelian Apotek Pusaka Arta untuk memperoleh informasi dalam pemilihan supplier.

b. Observasi
Observasi merupakan kegiatan pengumpulan data atau dokumen dengan cara mengamati hal-hal berkenaan dengan proses pemilihan supplier.

c. Studi Pustaka

Dilakukan dengan cara membaca jurnal atau $e$ book yang berkaitan dengan teori pemilihan supplier, dan teori lainnya yang berhubungan dengan pembuatan sistem pemilihan supplier ini .

d. Analisa Dokumen

Merupakan kegiatan menganalisa dokumen atau data agar memperoleh informasi yang akan digunakan untuk sistem.

\subsection{Studi Literatur}

1. Penelitian terkait dengan pemilihan supplier. diantaranya penelitian yang dilakukan oleh [4] dalam prosiding Vol.14 No.1 / Maret 2017, ISSN : 1978-2136. Mempunyai kriteria pengiriman, pelayanan, produk, kualitas, dan harga. Dan hasil nilai akhir yang tertinggi adalah suplier C 49\% dengan kualitas $26 \%$.

2. Penelitian selanjutnya dilakukan oleh [1] dalam prosiding Seminar Nasional SISFOTEK (Sistem Informasi dan Teknologi Informasi) ISSN 2597-3584. Memiliki kriteria diantaranya: diskon, tempo pembayaran, waktu pengiriman, kemasan, dan expired date. Diperoleh hasil nilai tertinggi adalah supplier $\mathrm{C}$ dengan nilai 0,8265 dan kriteria expired date dengan bobot 0,4146 .

\subsection{Analisa Masalah}

Masalah utama pada penelitian yang dilakukan di Apotek Pusaka Arta adalah proses pemilihan supplier yang tidak mudah. Pada proses pemilihan supplier yang kurang tepat akan berdampak pada ketersediaan obat. Dalam menentukan supplier, Apotek Pusaka Arta hanya berdasarkan pada diskon yang ditawarkan dan pengiriman yang cepat sehingga proses pemilihan supplier tidak mudah dan juga penyimpanan yang dilakukan untuk menyimpan data supplier kurang memadai. Masalah dalam memenuhi pesanan obat (order) yang dapat merugikan apotek, seperti jumlah obat yang dikirim tidak sesuai dengan pesanan, adanya kemasan yang rusak ,dan tanggal kadaluarsa yang dekat. Analisa masalah penelitian ini di gambarkan pada gambar 2 .

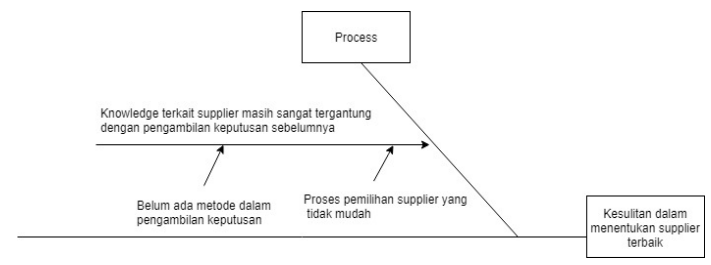

Gambar 2. Fishbone Diagram 


\section{HASIL DAN PEMBAHASAN}

\subsection{Proses Bisnis}

Bagian pembelian membuat daftar obat yang akan dibeli. Kemudian bagian pembelian menghubungi kandidat supplier, lalu menanyakan 3 hal yaitu diskon / bonus, tempo pembayaran, dan waktu pengiriman. Jika diskon $3 \%$ atau lebih maka bisa melanjutkan evaluasi supplier, tapi jika diskon kurang dari 3 \% maka supplier tersebut tidak berhak melanjutkan evaluasi supplier. Jika tidak ada diskon maka akan menanyakan bonus, jika ada bonus maka berhak melanjutkan evaluasi supplier, jika tidak ada maka tidak berhak melanjutkan evaluasi supplier. Selanjutnya mengecek berapa lama tempo pembayaran, jika tempo pembayaran 30 hari atau lebih maka supplier berhak meneruskan evaluasi supplier, tetapi jika tempo pembayaran kurang dari 30 hari maka tidak bisa melanjutkan evaluasi supplier. Kemudian bagian pembelian akan bertanya waktu pengiriman lalu membandingkan dengan supplier lain, jika pengiriman 2 hari atau kurang dari 2 hari maka supplier tidak bisa meneruskan evaluasi, tapi jika lebih dari 2 hari maka tidak bisa melanjutkan karena kebutuhan stok yang harus terpenuhi.

Setelah barang sampai maka bagian pengecekan akan mengecek ketepatan jumlah kirim, kemasan, dan tanggal kadaluarsa. Jika jumlah barang yang dikirim sesuai dengan yang dipesan maka proses evaluasi berlanjut, namun jika barang yang dikirimkan jumlahnya tidak sesuai maka proses evaluasi dihentikan. Selanjutnya mengecek kemasan, jika kemasan yang diberikan masih bagus dan dalam keadaan baik maka evaluasi supplier berlanjut, dan jika kemasan tidak bagus atau tidak layak maka evaluasi berhenti. Kemudian cek tanggal kadaluarsa, jika tanggal kadaluarsa 1 tahun atau lebih maka supplier tersebut berhak melanjutkan evaluasi, tetapi jika tanggal kadaluarsa kurang dari 1 tahun maka supplier tersebut tidak berhak melanjutkan evaluasi supplier. Jika kandidat supplier menawarkan retur maka waktu pengirimannya 2 hari atau kurang dari 2 hari maka evaluasi berlanjut, jika lebih dari 2 hari maka evaluasi tidak berlanjut.

Setelah melalui seluruh proses evaluasi dan pemesanan maka akan ada supplier yang sesuai dengan semua kriteria dan dijadikan calon supplier obat pada Apotek Pusaka Arta. Seperti pada gambar 3.

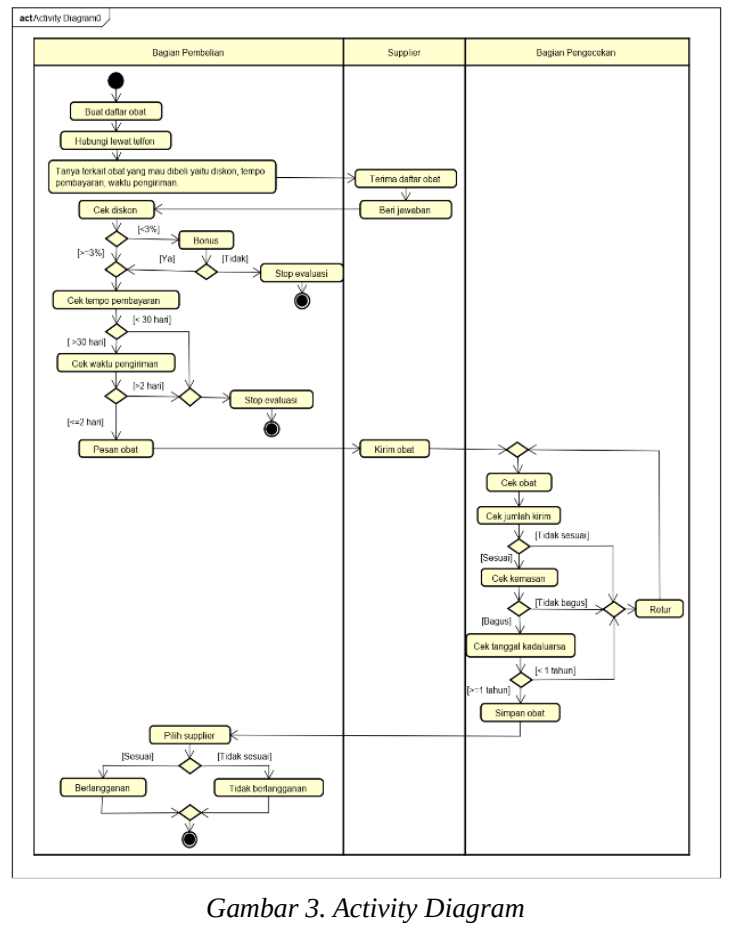

\subsection{Perhitungan Bobot dengan Metode AHP}

Perhitungan bobot ini diperoleh setelah bagian pembelian mengisi kuisioner yang membandingkan tingkat kepentingan kriteria (tabel 1).

Tabel 1. Perbandingan Kriteria

\begin{tabular}{|l|l|l|l|l|l|l|}
\hline Nama Kriteria & Kemasan & $\begin{array}{l}\text { Tanggal } \\
\text { Kadaluarsa }\end{array}$ & $\begin{array}{l}\text { Waktu } \\
\text { pengiriman }\end{array}$ & $\begin{array}{l}\text { Jumlah } \\
\text { Kirim }\end{array}$ & Diskon & $\begin{array}{l}\text { Tempo } \\
\text { Pembayaran }\end{array}$ \\
\hline Kemasan & 1 & 1 & $1 / 2$ & $1 / 4$ & $1 / 2$ & 1 \\
\hline Tanggal Kadaluarsa & 1 & 1 & 2 & 1 & 1 & $1 / 2$ \\
\hline Waktu Pengiriman & 2 & $1 / 2$ & 1 & $1 / 2$ & $1 / 2$ & $1 / 2$ \\
\hline Jumlah Kirim & 4 & 1 & 2 & 1 & 1 & 1 \\
\hline Diskon & 2 & 1 & 2 & 1 & 1 & 1 \\
\hline Tempo Pembayaran & 1 & 2 & 2 & 1 & 1 & 1 \\
\hline
\end{tabular}

Setelah dilakukan perhitungan maka peroleh eigenvector atau bobot seperti pada tabel 2 .

Tabel 2. Bobot Kriteria

\begin{tabular}{|c|l|c|}
\hline $\begin{array}{c}\text { Kode } \\
\text { Kriteria }\end{array}$ & \multicolumn{1}{|c|}{ Nama Kriteria } & Bobot \\
\hline K01 & Kemasan & 0,1051 \\
\hline K02 & Tanggal Kadaluarsa & 0,1619 \\
\hline K03 & Waktu Pengiriman & 0,1127 \\
\hline K04 & Jumlah Kirim & 0,2254 \\
\hline K05 & Diskon & 0,1932 \\
\hline K06 & Tempo Pembayaran & 0,2017 \\
\hline
\end{tabular}

\subsection{Perhitungan Ranking Dengan Metode SAW}

Data nilai alternatif dan kriteria pada tabel 3.3 didapat dari bagian pembelian. 
Tabel 3. Nilai Alternatif Per Kriteria

\begin{tabular}{|l|c|c|c|c|c|c|}
\hline Supplier & K01 & K02 & K03 & K04 & K05 & K06 \\
\hline Supplier A & 2 & 1 & 2 & 2 & 2 & 30 \\
\hline Supplier B & 2 & 2 & 1 & 1 & 3 & 30 \\
\hline Supplier C & 2 & 2 & 3 & 2 & 3,5 & 30 \\
\hline Supplier D & 1 & 2 & 2 & 2 & 2,5 & 30 \\
\hline Supplier E & 1 & 2 & 2 & 2 & 3,5 & 20 \\
\hline Supplier F & 2 & 1 & 2 & 2 & 2 & 30 \\
\hline
\end{tabular}

Dari data nilai alternatif pada tabel 3 mendapatkan matriks R sebagai berikut :

$$
R=\left[\begin{array}{cccccc}
1 & 0,5 & 0,5 & 1 & 0,5714 & 1 \\
1 & 1 & 1 & 0,5 & 0,8571 & 1 \\
1 & 1 & 0,3333 & 1 & 1 & 1 \\
0,5 & 1 & 0,5 & 1 & 0,7143 & 1 \\
0,5 & 1 & 0,5 & 1 & 1 & 0,6667
\end{array}\right]
$$

Setelah mendapatakan nilai dari matriks $\mathrm{R}$ dan nilai bobot (W) maka langkah selanjutnya ialah proses preferensi (Vi) dengan menggunakan formula

$$
V_{i}=\sum_{j=1}^{n} w_{j} \quad r_{i j}
$$

Bobot $(\mathrm{W})=\left[\begin{array}{llll}0,1051 & 0,1619 & 0,1127 & 0,2254\end{array}\right.$ 0,1932 0,2017]

Menjadi:

1) Supplier A

$V_{1}=\{(0,1051 \times 1)+(0,1619 \times 0,5)+(0,1127 \times 0,5)+$ $(0,2254 \times 1)+(0,1932 \times 0,5714)+(0,2017 \times 1)\}$

$=(0,1051)+(0.0809)+(0,0563)+(0,2254)+$

$(0,1104)+(0,2017)$

$=0,7800$

2) Supplier B

$V_{2}=\{(0,1051 \times 1)+(0,1619 x 1)+(0,1127 x 1)+(0,22$

$54 \times 0,5)+(0,1932 \times 0,8571)+(0,2017 \times 1)\}$

$=(0,1051)+(0,1619)+(0,1127)+(0,1127)+$

$(0,1656)+(0,2017)$

$=0,8597$

3) Supplier C

$V_{3}=\{(0,1051 \times 1)+(0,1619 x 1)+(0,1127 x(0,3333)$ $+(0,2254 \mathrm{x} 1)+(0,1932 \times 1)+(0,2017 \times 1)\}$

$=(0,1051)+(0,1619)+(0,0376)+(0,2254)+(0,193$ $2)+(0,2017)$

$=0,9249$

\section{4) Supplier D}

$V_{4}=\{(0,1051 \times 0.5)+(0,1619 \times 1)+(0,1127 \times 0,5)+(0$ $, 2254 \times 1)+(0,1932 \times 0,7143)+(0,2017 \times 1)\}$

$=(0,0525)+(0,1619)+(0,0563)+(0,2254)+$ $(0,1380)+(0,2017)$

$=0,8360$

5) Supplier E

$$
\begin{aligned}
& V_{5}=\{(0,1051 \times 0.5)+(0,1619 \times 1)+(0,1127 \times 0,5)+ \\
& \quad(0,2254 \times 1)+(0,1932 \times 1)+(0,2017 \times 0,6667)\} \\
& =(0,0525)+(0,1619)+(0,0563)+(0,2254)+ \\
& \quad(0,1932)+(0,1345) \\
& =0,8240
\end{aligned}
$$

a. Hasil Nilai Alternatif

Setelah melakukan pengolahan data (Tabel 4) maka dapat disimpulkan bahwa Supplier C adalah supplier terbaik dengan perolehan nilai 0,9249.

Tabel 4. Tabel Perangkingan

\begin{tabular}{|c|c|c|}
\hline Perankingan & Nama Alternatif & Nilai Akhir \\
\hline 1 & PT. Kimia Farma & 0,9249 \\
\hline 2 & PT. Era Sejahtera & 0,8597 \\
\hline 3 & & 0,8360 \\
\hline 4 & PT. Raja Wali & 0,8240 \\
\hline 5 & PT. Enseval & 0,7800 \\
\hline & PT. Anugerah Argon & \\
\hline
\end{tabular}

Jika terjadi hasil nilai yang sama maka keputusan tergantung bagian pembelian .

\subsection{Perancangan Sistem}

Use Case diagram dalam perancangan sistem terdapat 3 usecase yaitu Master, Process, dan Laporan. pada gambar 4, 5 dan 6. Pada Gambar 4 terdiri atas Entry Supplier, Entry Kriteria. Pada gambar 5 terdiri atas Perbandingan Tingkat Kepentingan, Pemilihan Alternatif, Penilaian Alternatif dan Penentuan Hasil Keputusan. Dan pada gambar 6 terdiri atas Cetak Laporan Evaluasi, Cetak Laporan Ranking dan Cetak Laporan Supplier Terpilih.

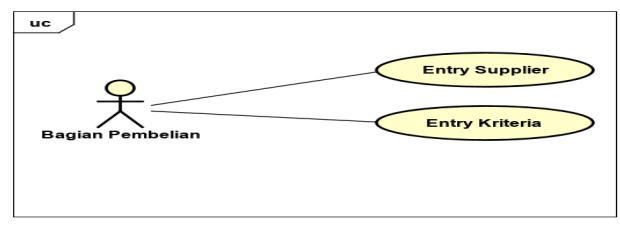

Gambar 4. Use Case Diagram Master

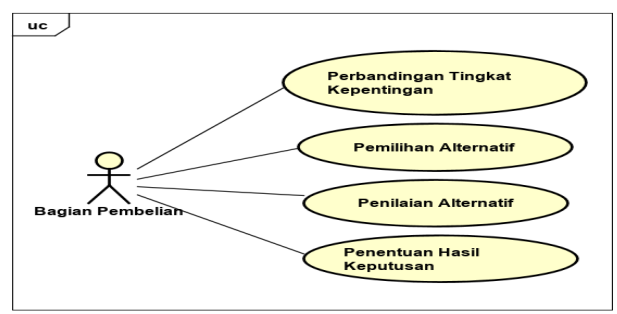

Gambar 5. Use Case Diagram Process 


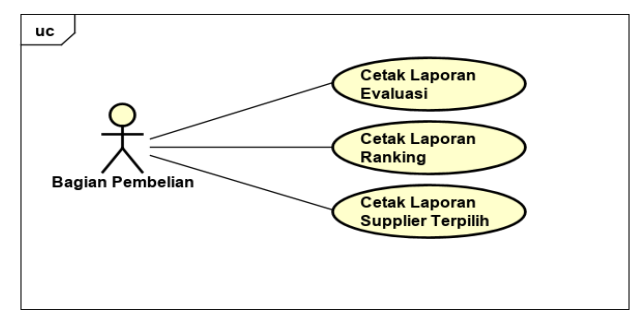

Gambar 6. Use Case Diagram Laporan

\subsection{Rancangan Layar Pada Sistem}

\section{a. Menu Utama}

Saat sistem dijalankan, form menu utama akan muncul akan muncul (Gambar 7). Terdapat tiga menu yaitu Master, Perhitungan, dan Laporan. Masing-masing menu memiliki sub-menu. Menu Master mempunyai sub-menu supplier dan kriteria. Kemudian Menu Perhitungan mempunyai sub-menu perbandingan tingkat kepentingan, pemilihan alternatif, penilaian alternative, dan penentuan hasil keputusan. Dan menu Laporan mempunyai submenu evaluasi, ranking, dan supplier terpilih.

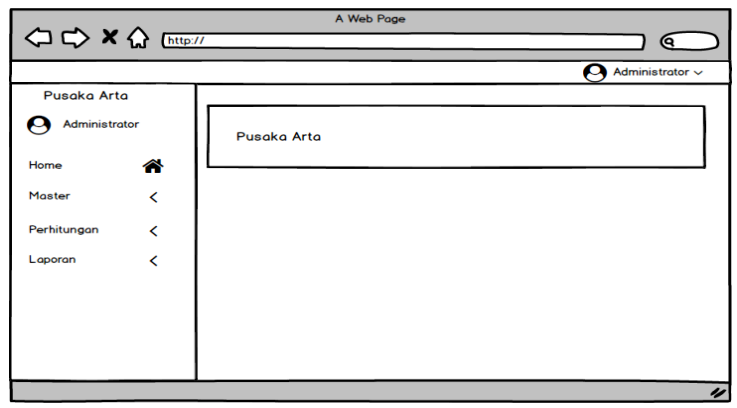

Gambar 7. Rancangan Layar Menu Utama

\section{b. Supplier}

Rancangan Layar Entry Data Supplier (Gambar 8), terdapat pada menu bar input. Pada form entry data supplier terdapat nama supplier, nomer telepon dan alamat supplier. Dimana nama supplier dimasukkan pada textbox nama supplier, nomor telepon dimasukkan pada textbox nomor telepon supplier, dan alamat supplier dimasukkan pada textbox alamat supplier. Untuk menyimpan data terdapat botton simpan dan untuk kembali terdapat button kembali.

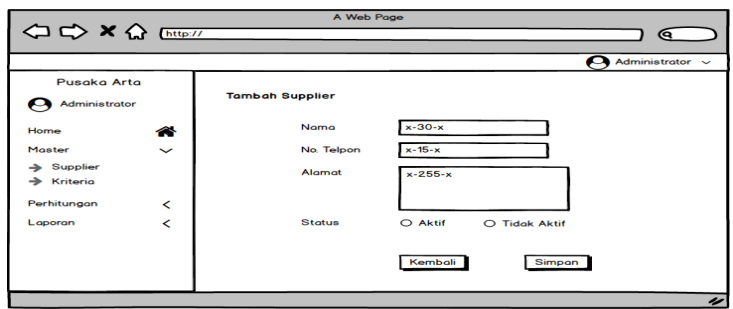

Gambar 8. Rancangan Layar Entry Data Supplier c. Perbandingan Tingkat Kepentingan

Rancangan Layar Entry Perbandingan Tingkat Kepentingan (Gambar 3.7), terdapat menu bar num.stepper dan radio button. Dimana memilih perbandingan yang lebih penting menggunakan radio button dan nilai perbandingan menggunakan num.stepper.

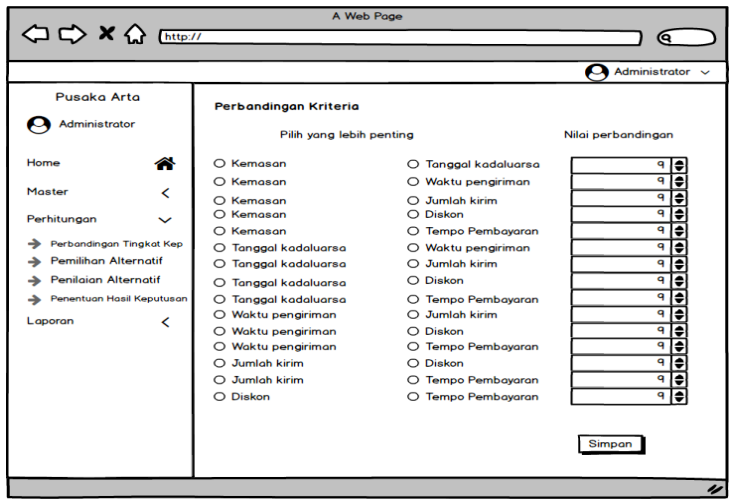

Gambar 9. Rancangan Layar Entry Perbandingan Tingkat Kepentingan

\section{d. Perangkingan}

Rancangan Layar Laporan Perangkingan (Gambar 10), terdapat menu bar combo box, button Cari, dan button Export to pdf. Jika ingin mencetak laporan perangkingan, terlebih dahulu memilih tanggal kemudian klik button cari kemudian klik button Export to pdf untuk cetak laporan. Untuk keluar dari form dengan klik tombol close (X).

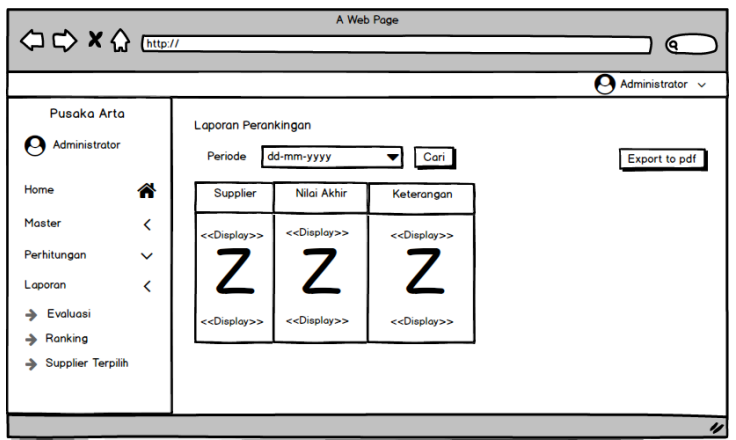

Gambar 10. Rancangan Layar Laporan Perangkingan

\section{KESIMPULAN}

Dari penelitian yang dilakukan pada Apotek Pusaka Arta, terdapat beberapa kesimpulan diantaranya :

a) Proses penyimpanan data pada sistem penunjang keputusan dalam bentuk database, sehingga memudahkan data diolah dan diakses dengan cepat.

b) Sistem penunjang keputusan dapat membantu Bagian Pembelian Apotek Pusaka Arta dalam 
menentukan pemilihan supplier terbaik.

c) Dalam pembobotan kriteria pemilihan supplier dilakukan dengan menggunakan metode AHP yaitu melakukan perbandingan nilai kriteria berdasarkan kuesioner yang diisi oleh bagian pembelian. Dan metode SAW sebagai proses penjumlahan nilai supplier terbaik.

Adapun saran mengenai pemilihan supplier pada Apotek Pusaka Arta dengan metode AHP dan SAW yaitu :

a) Ketelitian dalam penginputan data untuk memaksimalkan hasil keputusan.

b) Dibutuhkan pelatihan kepada pengguna yang menggunakan sistem penunjang keputusan ini, agar mudah dalam mengoperasikan sistem dengan benar.

\section{DAFTAR PUSTAKA}

[1] A. Y. Pradipta and A. Diana, "Sistem Penunjang Keputusan Pemilihan Supplier Pada Apotek Dengan Metode AHP Dan SAW ( Studi Kasus Apotek XYZ ),” pp. 107-114, 2017.

[2] C. Trimulia, S. Defit, and G. W. Nurcahyo, "Pemilihan Supplier Obat Yang Tepat Dengan Metode Simple Additive Weighting," J. Sains, Teknol. dan Ind., vol. 16, no. 1, pp. 37-42, 2018.

[3] Y. Anis, H. Listiyono, and T. Khristianto, "Analytic Hierarchy Process (AHP) Sebagai Alat Untuk Pengambilan Keputusan (SPK) Seleksi Pemasok Obat-Obatan,” vol. 7, no. 2, pp. 92-101, 2015.

[4] R. I. Handayani and Y. Darmianti, "Pemilihan Supplier Bahan Baku Bangunan Dengan Metode Analytical Hierarchy Process (AHP) Pada PT. Cipta Nuansa Prima Tangerang,” J. Techno Nusa Mandiri, vol. 14, no. 1, pp. 1-8, 2017. 